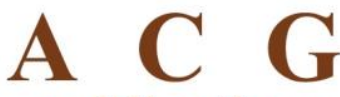

J. Chem. Metrol. 13:1 (2019) 7-13

journal of chemical

metrology

publications

\title{
Determination of some heavy metals by ICP-OES in edible parts of fish from Sapanca Lake and streams
}

\author{
Huseyin Altundag ${ }^{*}$, Ebru Yıldırım and Esra Altıntıg \\ Sakarya University, Faculty of Arts and Sciences, Department of Chemistry, 54187, \\ Sakarya, Türkiye
}

(Received March 18, 2019; Revised June11, 2019; Accepted June 14, 2019)

\begin{abstract}
In this study, 20 fish taken from Sapanca Lake, Sakarya River and Western Black Sea (Karasu) in total and heavy metal accumulation $(\mathrm{Cu}, \mathrm{Fe}$ abd $\mathrm{Zn})$ in the muscles of 15 species was determined with ICP-OES (Inductively Coupled Plasma-Optical Emission Spectometer) device. When the results were examined, $\mathrm{Cu}, \mathrm{Fe}$ and $\mathrm{Zn}$ concentration was determined to be $2.60-5.31 \mu \mathrm{g} / \mathrm{g}, 0.25-54.36 \mu \mathrm{g} / \mathrm{g}$ and $13.66-47.11 \mu \mathrm{g} / \mathrm{g}$ respectively in fish samples. In addition, the same procedures were applied with the standard reference material DORM-3 reference material (Fish Protein Certified Reference Material for Trace Metals) to determine the accuracy of the method. As a result, it has been determined that the amount of heavy metals contained in the analyzed fish samples is below the limit values provided by the Turkish Food Codex, Food and Agriculture Organization and World Health Organization and therefore consumption of these does not constitute a threat to health.
\end{abstract}

Keywords: Heavy metals; fish; ICP-OES; microwave digestion. @ 2019 ACG Publications. All rights reserved.

\section{Introduction}

Fish have a very rich and important place in terms of protein among the foods consumed in human life [1]. It is known that fish have an important role in the prevention of many diseases, from heart diseases to depression with A, B1, B2 and D vitamins they contain, as well as being rich in phosphorus, calcium and iodine besides protein [2].

Environmental pollution occurring in the ecosystem is a situation containing air, soil and water pollution. Because the pollutants released into the air and into the earth do not remain stable in the environment, they are in, but they cause pollution by mixing with the surface and the ground water by means of floods and rain [3]. Industrial and urban wastewater, which are one of the most important causes of water pollution, has an important effect on the quality of the inland water system due to settlements or industrial facilities in the environment [4]. The heavy metals which exist in especially industrial wastes and some pesticides and disturb the balance between the living things in the ecosystem, are very important since they are able to stay in the environment where they are discharged for a long time, they cause toxic effects on aquatic organisms and they threaten human health by accumulating in the food chain $[5,6]$.

Recently, modern agricultural practices and the rapid increase of industrial enterprises with the population increase have led to heavy metal accumulation in the aquatic environments [7-9]. One of the main causes of environmental pollution is toxic elements. Toxic elements can be very harmful

\footnotetext{
* Corresponding author E-Mail: altundag@ @akarya.edu.tr
} 
even at low concentrations [10]. With this increase in the concentration of toxic metals as marine pollution in aquatic environment, environment problems threatening the natural balance and the health of the living things increase day by day [11]. Under normal conditions, the proportion of heavy metals in the environment is low. Heavy metals such as silver, mercury, copper, cadmium and lead create toxic effects on organisms when the concentration of heavy metals increases in the natural environment [12]. Heavy metals can harm living organisms and especially humans [13]. Hence, heavy metals among pollutants have a large ecological importance [9]. The heavy metal accumulation in the fish consumed as an important protein source is transferred to the upper levels of the food chain in increasing amounts leading to the toxic effect, which in turn can adversely affect human health [14]. There are many studies about trace metal analysis in fishes in the world and our country $[1,6,7,9,10$, $15,16]$.

In this study, concentrations of some heavy metals $(\mathrm{Cu}, \mathrm{Fe}$ and $\mathrm{Zn})$ were determined by ICPOES in 15 different fish species, in total of 20 fish from Lake Sapanca, Sakarya River and Western Black Sea (Karasu). The data obtained from the study were compared with the literature and the Turkish Food Codex [17] (TFC), Food and Agriculture Organization [18] (FAO) and World Health Organization (WHO) standards.

\section{Experimental}

\subsection{Preparation of Samples for Analysis}

In this study, 20 fish of 15 different species (Tinca tinca, Cyprinus carpio, Squalius cephalus, Salmo trutta, Scardinius erythrophthalmus, Perca fluviatilis, Abramis brama, Esocidae, Silurus glanis, Pomatomus saltatrix, Mugil labeo, Trachurus trachurus, Sardina pilchardus, Mullus barbatus, Micromesistius poutassau, Cyprinus carpio, Scardinius erythrophthalmus, Squalius cephalus, Silurus glanis, Abramis brama) were obtained from Sapanca Lake, Sapanca River Western Black Sea (Karasu) between September 2016 and June 2017, and were brought to the laboratory for analysis (see Figure S1 in supporting information). The internal organs, head, tail and scales of the fish specimens were cleaned and edible parts were cleaned using a stainless steel blade and washed with ultrapure water. The prepared samples were dried at $110{ }^{\circ} \mathrm{C}$ in drying oven for about 4 hours. Porcelain mortar was used to powder the samples and homogenization was provided.

\subsection{Chemicals}

The glass and plastic materials used in this study were cleaned using a $10 \% \mathrm{HNO}_{3}$ solution and used by rinsing in ultra-pure water. Ultrapure water (Milli-Q Millipore $18.2 \mathrm{M} \Omega . \mathrm{cm}$ ) was used for all aqueous solutions. The chemicals used for the analysis were selected of high quality chemicals (Ultrapure hydrochloric acid (30\%, w/w), Ultrapure nitric acid (65\%,w/w) Merck). For the calibration solutions, $1000 \mu \mathrm{g} / \mathrm{mL}$ ICP multi element standard solution supplied by Merck was used. The precison and accuracy of the analysis results were checked using the standard reference material (DORM-3 Fish).

\subsection{Devices}

ICP-OES (Inductively Coupled Plasma-Optical Emission Spectrometer, Spectro Analytical Instruments, Kleve, Germany) was used to determine the concentrations of all the elements studied. The microwave used to dissolve powdered solid samples was CEM MARS 6 / Easy Prep Plus Vessel System. Analytical conditions of instruments used in trace element analysis are given in Table S1 in supporting information. 


\subsection{Sample Shredding Process}

After the fish samples were obtained and brought to the laboratory environment, the muscle tissues were cleaned and the tissues was dried in drying oven and homogenized in porcelain mortar. A microwave device was used to dissolve muscle tissue in fish samples [19]. In the microwave method used in the study, $0.225 \mathrm{~g}$ of reference material and fish specimens were processed as doubles. For this method; different acid mixtures were used in the form of $\mathrm{HNO}_{3} / \mathrm{H}_{2} \mathrm{O}_{2}:(6: 2), \mathrm{HNO}_{3} / \mathrm{HCl}(3: 1)$, $\mathrm{HNO}_{3} / \mathrm{HCl}(1: 3)$ and $\mathrm{HNO}_{3} / \mathrm{H}_{2} \mathrm{SO}_{4}(6: 2)$ Among the methods, inverse aqua regia $\left(\mathrm{HNO}_{3} / \mathrm{HCl}(3: 1)\right)$ was the most appropriate, and the study was continued with these solutions [20]. Samples were prepared and were measured to be $25 \mathrm{~g}$ and dissolved in the microwave system by adding $3 \mathrm{~mL}$ of $65 \% \mathrm{HNO}_{3}$ and $1 \mathrm{~mL}$ of $30 \% \mathrm{HCl}$. A 35-minute program was used for the dissolving process. According to the food program created, the work went on for a total of 35 minutes at $300{ }^{\circ} \mathrm{C}$ with 1200-1800 watts of power. The device reached $300{ }^{\circ} \mathrm{C}$ in the first 15 minutes and continued the process for 5 minutes at that temperature and cooled down within the last 15 minutes. At the end of the process, the solutions were completed to $10 \mathrm{~mL}$ volume with ultra-pure water.

\subsection{Validation of Analytical Methods}

The performance of the methods used was evaluated in terms of linearity, recovery and precision. The accuracy of the methods was checked using Fish Protein (Dorm-3 Fish) certified reference materials for concentrations of $\mathrm{Cu}, \mathrm{Fe}$ and $\mathrm{Zn}$ elements.

Table 1. Physical properties of fish samples

\begin{tabular}{|c|c|c|c|}
\hline Location & Fish Species & $\begin{array}{c}\text { Length } \\
(\mathrm{cm})\end{array}$ & $\begin{array}{l}\text { Weight } \\
\text { (g) }\end{array}$ \\
\hline \multirow{9}{*}{ Sapanca Lake } & Tinca tinca & 17 & 280 \\
\hline & Cyprinus carpio & 32 & 1200 \\
\hline & Squalius cephalus & 28 & 500 \\
\hline & Salmo trutta & 19 & 340 \\
\hline & Scardinius erythrophthalmus & 16 & 220 \\
\hline & Perca fluviatilis & 18 & 200 \\
\hline & Abramis brama & 15 & 200 \\
\hline & Esox Lucius & 30 & 850 \\
\hline & Silurus glanis & 40 & 1600 \\
\hline \multirow{4}{*}{ Sakarya River } & Cyprinus carpio & 25 & 1000 \\
\hline & Scardinius erythrophthalmus & 18 & 350 \\
\hline & Squalius cephalus & 20 & 250 \\
\hline & Silurus glanis & 45 & 2000 \\
\hline \multirow{7}{*}{$\begin{array}{l}\text { Western Black } \\
\text { Sea (Karasu) }\end{array}$} & Abramis brama & 16 & 200 \\
\hline & Pomatomus saltatrix & 15 & 120 \\
\hline & Mugil labeo & 13 & 170 \\
\hline & Trachurus trachurus & 11 & 80 \\
\hline & Sardina pilchardus & 9 & 60 \\
\hline & Mullus barbatus & 7 & 50 \\
\hline & Micromesistius poutassau & 8 & 60 \\
\hline
\end{tabular}




\section{Results and discussion}

\subsection{Determination of the Trace Elements in Fish Muscle}

Microwave dissolution methods were applied to the samples and the concentrations of the elements were determined by ICP-OES instrument. The physical characteristics of fish are as shown in Table 1.

The certified reference material Dorm-3 Fish was used to compare the accuracy of the microwave methods used to dissolve the sampled fish samples and the results are given in Table 2.

Table 2. Concentrations of certified and observed trace elements in DORM-3 fish protein $(\mu \mathrm{g} / \mathrm{g})$.

\begin{tabular}{cccc}
\hline Element & Certified Value & $\begin{array}{c}\text { Microwave } \\
\text { Value }\end{array}$ & $(\boldsymbol{\%})$ Recovery \\
\hline $\mathbf{C u}$ & $15.5 \pm 0.63$ & $14.9 \pm 1.03$ & 96 \\
$\mathbf{F e}$ & $347 \pm 20$ & $330 \pm 14$ & 95 \\
$\mathbf{Z n}$ & $51.3 \pm 3.1$ & $49.5 \pm 2.9$ & 96 \\
\hline
\end{tabular}

When all the studies performed are examined, the recovery values of the MW method varies around $95-96 \%$. Concentrations of the elements after the solubilization process were identified with ICP-OES device on dry basis. As a result of this study, trace elements concentrations in muscle tissues of 20 fish of 15 different fish species are given in Table 3.

Table 3. Concentrations for fish species obtained by ICP- OES (dry weight).

\begin{tabular}{cccc}
\hline Fish Species & $\mathbf{C u}$ & $\mathbf{F e}$ & $\mathbf{Z n}$ \\
\hline Tinca tinca & $3.52 \pm 0.02$ & $25.87 \pm 2.12$ & $39.99 \pm 3.65$ \\
Cyprinus carpio & $3.25 \pm 0.08$ & $19.39 \pm 1.75$ & $47.11 \pm 4.63$ \\
Squalius cephalus & $3.78 \pm 0.07$ & $32.88 \pm 3.19$ & $42.00 \pm 4.52$ \\
Salmo trutta & $3.43 \pm 0.09$ & $13.80 \pm 2.16$ & $37.68 \pm 3.46$ \\
Scardinius erythrophthalmus & $2.67 \pm 0.03$ & $15.76 \pm 0.41$ & $25.67 \pm 2.46$ \\
Perca fluviatilis & $5.31 \pm 0.08$ & $14.96 \pm 1.06$ & $34.98 \pm 3.63$ \\
Abramis brama & $3.47 \pm 0.05$ & $30.48 \pm 1.36$ & $22.79 \pm 1.32$ \\
Esox Lucius & $2.60 \pm 0.0 .6$ & $10.25 \pm 1.61$ & $22.20 \pm 2.31$ \\
Silurus glanis & $3.42 \pm 0.06$ & $38.06 \pm 3.81$ & $44.97 \pm 4.54$ \\
Cyprinus carpio & $3.15 \pm 0.02$ & $33.53 \pm 4.32$ & $31.02 \pm 3.62$ \\
Scardinius erythrophthalmus & $2.82 \pm 0.01$ & $20.77 \pm 2.52$ & $23.47 \pm 2.61$ \\
Squalius cephalus & $3.02 \pm 0.02$ & $30.28 \pm 3.14$ & $13.66 \pm 1.41$ \\
Silurus glanis & $2.75 \pm 0.06$ & $24.36 \pm 3.07$ & $15.60 \pm 1.59$ \\
Abramis brama & $3.29 \pm 0.06$ & $20.73 \pm 1.85$ & $22.33 \pm 3.63$ \\
Pomatomus saltatrix & $3.28 \pm 0.04$ & $18.81 \pm 1.95$ & $18.23 \pm 2.45$ \\
Mugil labeo & $4.19 \pm 0.05$ & $31.40 \pm 4.11$ & $17.29 \pm 2.51$ \\
Trachurus trachurus & $4.91 \pm 0.07$ & $34.72 \pm 3.21$ & $28.38 \pm 1.36$ \\
Sardina pilchardus & $4.57 \pm 0.05$ & $40.06 \pm 4.92$ & $30.46 \pm 1.82$ \\
Mullus barbatus & $3.06 \pm 0.09$ & $54.36 \pm 5.13$ & $27.27 \pm 2.78$ \\
Micromesistius poutassau & $4.16 \pm 0.08$ & $26.19 \pm 2.71$ & $25.15 \pm 3.16$ \\
\hline
\end{tabular}

The trace element levels of the determined trace elements as shown in Table 4, were found to be, respectively; $\mathrm{Cu}: 2.60-5.31 \mu \mathrm{g} / \mathrm{g}$, Fe: 10.25-40.06 $\mu \mathrm{g} / \mathrm{g}$, and $\mathrm{Zn}: 13.66-47.11 \mu \mathrm{g} / \mathrm{g}$. While the 
highest heavy metal level was iron, the lowest heavy metal level was identified as lead in the fish samples in this study. Similar results have been reported by many investigators [7, 10, 21, 22].

Copper is a very common metal with natural spreading around [23]. Copper slows growth when it is present in small amounts in living organism, but it causes toxic effect in living organism when it is present in excess amount [24]. In terms of human body functions, copper is especially the core component of especially the hair and the resilient parts of the skin, bones and some internal organs. Copper deficiency can result in blood and nervous system disorders in adults [25]. In many species of fish, copper causes a decrease in the taste sense, serious adverse effects on feeding and reproductive behavior [26]. In fish studies conducted by Türkmen et al. in 2009 in the Aegean and Mediterranean regions, the concentrations of copper in the fish were reported to be $0.51-7.05 \mu \mathrm{g} / \mathrm{g}$ [27]. In another study conducted by Tokatli et al., the concentrations of the lowest and highest copper element in the muscular tissues of fishes in the Gala Lake and Meriç River were found to be 1.36-3.23 $\mu \mathrm{g} / \mathrm{g}$ and 1.89-3.88 $\mu \mathrm{g} / \mathrm{g}$, respectively [28]. Silva E. et al. (2015) reported that the lowest copper concentration was $2,0 \mu \mathrm{g} / \mathrm{g}$, and $33.7 \mu \mathrm{g} / \mathrm{g}$ was the highest copper concentration in various fish species [29]. The lowest and highest copper concentrations in muscle tissue of the fishes obtained in this study was observed in the fishes of Sapanca lake, the lowest copper concentration was found to be $2.60 \mu \mathrm{g} / \mathrm{g}$ in Esocidae fish species and the highest copper concentration was found to be $5.31 \mu \mathrm{g} / \mathrm{g}$ in Perca fluviatilis species. The maximum copper content allowed by Turkish Food Codex was specified as 20 $\mu \mathrm{g} / \mathrm{g}$. According to $\mathrm{FAO} / \mathrm{WHO}$, the amount of copper that can be tolerated per day (based on body weight of $60 \mathrm{~kg}$ ) is determined to be $3 \mathrm{mg}$. In our study, the concentrations of copper in muscle tissues of fish were below the legal limit.

Iron is one of the nutritional items that cannot be synthesized in our bodies and which must be taken with foods. It is a very important mineral for our bodies in terms of benefits [30]. High amounts of iron can cause tissue fractionation, coronary heart disease and cancer. When colloidal iron is very dense in aquatic environments, it can accumulate on the gills of fish and cause death. Similar studies related to the determination of iron levels in the fish in Turkey exist. In the study conducted by Tüzen in 2009 , iron concentration was found to be $36.2-110 \mu \mathrm{g} / \mathrm{g}$ [31], in the study conducted by Mendil et al. iron concentration was found to be $5-70.1 \mu \mathrm{g} / \mathrm{g}$ [20], in the study conducted by Tuzen and Soylak in 2007 , the concentration of iron in the canned fish purchased from the grocery stores was 10.2-30.3 $\mu \mathrm{g} / \mathrm{g}$ [7], in the study conducted by Uluozlu et al. the concentration of iron was determined to be 68.6$163 \mu \mathrm{g} / \mathrm{g}$ in fish from coasts of the Black Sea and Mediterranean [10]. Daily tolerable iron value was determined to be $48 \mathrm{mg}$ by FAO/WHO, based on body weight (according to body weight of $60 \mathrm{~kg}$ ). In our study, the highest Fe concentration was found to be $40.06 \mu \mathrm{g} / \mathrm{g}$ in the Sardina pilchardus fish species, which was taken from the Western Black Sea (Karasu), and the lowest Fe concentration was found to be $10.25 \mu \mathrm{g} / \mathrm{g}$ in the Esocidae fish species which was taken from Sapanca Lake. When compared to these values, the iron concentration in our study is in harmony with other studies and does not pose any problem of consumption by being below legal limits.

Zinc, which has superior properties in biological trace elements, is one of the essential elements for growth and DNA self-replication for all cells. Naturally, it enters into the structure of very important proteins, acting in the active regions of the enzymes [32], Zinc is usually found in trace amounts in aquatic environments, and is found at increasing concentrations, mainly due to the effects of anthropogenic sources such as industrial, mining and agricultural activities. As a consequence, aquatic organisms, including fish, are under the influence of increasing concentrations of metals [23]. It has been reported in the literature that the zinc concentration in the fish muscles obtained from the Black Sea shores was 9.5-22.9 $\mu \mathrm{g} / \mathrm{g}$ [15]. In a different study, zinc levels in fish were reported to be $45.0-60.9 \mu \mathrm{g} / \mathrm{g}$. When we consider the zinc concentrations in fish species in our study, the lowest and highest values were found to be 13.66-47.11 $\mu \mathrm{g} / \mathrm{g}$. The rate of zinc given by Turkish Food Codex for fish is $50 \mu \mathrm{g} / \mathrm{g}$. Daily tolerable zinc value was determined to be $60 \mathrm{mg}$ by FAO/WHO, based on body weight. The zinc concentrations we achieved in our study were observed to be below the limit values.

\section{Conclusions}

Fish consumption, which is one of the main food sources in our country which is surrounded by sea on 3 sides, is very important in terms of the proteins and vitamins it contains. In this study, a 
total of 20 fish of 15 species were taken from Sapanca Lake, Sakarya River and Western Black Sea (Karasu) and $\mathrm{Cu}, \mathrm{Fe}$ and $\mathrm{Zn}$ trace element levels were determined by ICP-OES. According to the trace element results in the analyzed fish the analyzed fish do not have any risks for human health.

\section{Acknowledgements}

I would like to thank Sakarya University Scientific Research Projects (BAP) Commission Presidency (Project No: 2017-50-01-018) and TÜBİTAK ÇAYDAG (Project No: 115Y720) for their support for the study.

\section{Supporting Information}

Supporting information accompanies this paper on http://www.acgpubs.org/journal/journal-ofchemical-metrology

\section{ORCID}

Huseyin Altundağ 0000-0002-3675-4133

Ebru Y1ldirım: 0000-0002-6289-0729

Esra Altıntı̆̆: 0000-0001-8031-2415

\section{References}

[1] A. Velusamy, P. Satheesh Kumar and S. Anirudh Ram (2014). Bioaccumulation of heavy metals in commercially important marine fishes from Mumbai Harbor, India, Marin. Poll. Bull. 81, 218-224.

[2] J.L. Domingo, A. Bocio, G. Falco and J.M. Lobet (2007). Benefits and risks of fish consumption: Part I. A quantitative analysis of the intake of omega-3 fatty acids and chemical contaminants, Toxicology 230 (2-3) 219-226.

[3] H. Kaptan and S. Tekin-Özan (2014). Eğirdir Gölü'nün (Isparta) suyunda, sedimentinde ve gölde yaşayan sazan'ın (Cyprinus carpio L., 1758) bazı doku ve organlarındaki ağır metal düzeylerinin belirlenmesi, SDÜ Fen Derg. 9(2) 44-60.

[4] E. Kesici and C. Kesici (2006). Eğirdir Gölü (Isparta)'nün doğal yapısına yapılan müdahalelerin gölün ekolojik yapısına etkileri, Su Ürünleri Derg. 23(1) 99-103.

[5] A. Arulkumar, S. Paramasivam and R. Rajaram (2017). Toxic heavy metals in commercially important food fishes collected from Palk Bay, Southeastern India, Mar. Poll. Bull. 119, 454-459.

[6] D. Webb and M.M. Gagnon (2002). Biomarkers of exposure in fish inhabiting the Swan-canning estuary Western Australia-a preliminary study, J. Aquatic Ecos. Stress. Reco. 9(4) 259-269.

[7] M. Tuzen and M. Soylak (2007) Determination of trace metals in canned fish marketed in Turkey, Food Chem. 101, 1378-1382.

[8] A. Gundogdu and M. Erdem (2008) The Accumulation of the heavy metals (copper and zinc) in the Tissues of rainbow trout (Onchorhyncus mykiss, walbaum 1792), J. Fish. Sci. 2 (1) 41-50.

[9] M. Kalay, M.K. Sangün, D. Ayas and M. Göçer (2008) Chemical Composition and some trace element levels of thinlip mullet, liza ramada caught from Mersin Gulf, Ekoloji 68, 11-16.

[10] O. D. Uluozlu, M. Tuzen, D. Mendil and M. Soylak (2007) Trace metal content in nine species of fish from the Black and Aegean Seas, Turkey, Food Chem. 104, 835-840.

[11] E. Erdogdu and F. Erbilir (2007) Heavy metal and trace elements in various fish samples from Sir Dam Lake, Kahramanmaraş, Turkey, Environ. Monit. Assess. 130 (1-3) 373-379.

[12] O. Algan, N. Balkıs, N. Çağatay and E. Sari (2004). The sources of metal contents in the shelf sediments from the Marmara Sea, Environ. Geol. 46,932- 951.

[13] V. Türkoğlu, M. Ciftçi and A. Coban (2007) Effects of some drugs on hepatic glucose 6-phosphate dehydrogenase activity in Lake Van Fish (Chalcalburnus Tarischii Pallas, 1811), J. Hazard. Mater. 143, 415-418.

[14] A. Ikem and N.O. Egiobur (2005) Assessment of trace elements in canned fishes (Mackerel, Tuna, Salmon, Sardines and Herrings) marketed in Georgia and Alabama (United States of America), J. Food Compos. Anal. 18, 771-787.

[15] S. Topcuoglu, Ç. Kırbaşoğlu and N. Güngör (2002) Heavy metals in organs and sediment from Turkish coast of the Black Sea, 1997-1998, Environ. Int. 27(7) 521-526. 
[16] M. Tuzen (2003) Determination of heavy metals in fish samples of the middle Black Sea (Turkey) by graphite furnace atomic absorption spectrometry, Food Chem. 80, 119-123.

[17] Turkish Food Codex (2008) Regulation of setting maximum levels for certain contaminants in foodstuffs, Official Gazette 26879.

[18] FAO/WHO. Joint FAO/WHO (2010) Expert consultation on the risks and benefits of fish consumption, Rome, Italy, 25-29 January 2010. EC: RBFC/2010/3.

[19] L. Makedonski, K. Peycheva and M. Stancheva (2017). Determination of heavy metals in selected black sea fish species, Food Control, 72, 313-318.

[20] D. Mendil, Ö.F. Ünal, M. Tüzen, M. Soylak (2010) Determination of trace metals in different fish species and sediments from the Yesilirmak in Tokat, Turkey, Food Chem. Toxicol. 48(5) 1383-1392.

[21] B. Cicik (2003) Bakır-çinko etkileşiminin sazan (Cyprinus carpio) nun karaciğer, solungaç ve kas dokularındaki metal birikimi üzerine etkileri, Ekol. Çevre Derg. 48 (12) 32-36.

[22] F. E. Kayhan, M.N. Muşlu and N.D. Koç (2009) Bazi ağir metallerin sucul organizmalar üzerinde yarattiği stres ve biyolojik yanitlar, J. Fish. Sci. 3(2) 153-162.

[23] M. H. Dabbaghmanesh, N. M. Salehi, J. Siadatan and G. R. Omrani (2001) Copper concentration in a healthy urban adult population of Southern Iran Mohammad, Biol. Trace Elem. Res. 144 (1-3) 217-224.

[24] A. Uçar and M. Atamanalp (2009) Balıklarda toksikopatolojik lezyonlar II, Atatürk Üniv.Ziraat Fak. Derg. 40(1) 95-101.

[25] M. Turkmen, A.Turkmen, Y. Tepe, Y. Tore and A. Ates (2009) Determination of metals in fish species from Aegean and Mediterranean Seas, Food Chem. 113(1) 233-237.

[26] C. Tokatlı, Ö. Emitoğlu, A. Çiçek, E. Köse, S. Başkurt,S. Aksu, A. Uğurluoğlu and M. Şahin (2016) Meriç Nehri deltası (Edirne) balıklarında toksik metallerin biyolojik birikimlerinin araştırılması, Anadolu Üniv. Bilim Teknol. Derg. C, 5(1) 1-11.

[27] E. Silva, Z.C. Viana, N.F.A.Souza, M.G.A. Korn and V.L.C.S. Santos (2016) Assessment of essential elements and chemical contaminants in thirteen fish species from the Bay Aratu, Bahia, Brasil, Braz. J. Biol. 76(4) 871-877.

[28] A. Baysal (2002) Beslenme, 9. Bask1, Hatiboğlu Yayınevi, Ankara.

[29] M. Tuzen (2009) Toxic and essential trace elemental contents in fish species from the Black Sea, Turkey, Food Chem. Toxicol. 47(8) 1785-1790.

[30] M. Stefanidou, C. Maravelias, A. Dona and C. Spiliopoulou (2006) Zinc: A multipurpose trace element.,Arch Toxicol, 80, 1-9.

[31] H. M. Leung, A.O.W. Leung, H.S. Wang, K.K. Ma, Y. Liang, K.C. Ho, K.C. Cheung, F. Tohidi and K.K.L. Yung (2014) Assessment of heavy metals/metalloid (As, Pb, Cd, Ni, Zn, Cr, Cu, Mn) concentrations in edible fish species tissue in the Pearl River delta (PRD),China, Mar. Pollut. Bull. 78, 235-245.

[32] O. D. Uluozlu, M. Tuzen, D. Mendil and M. Soylak (2009) Assessment of trace element contents of chicken products from Turkey, J. Hazard. Mat. 163, 982-987

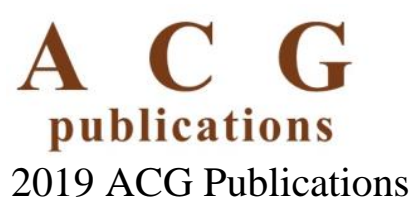

